\title{
The Influence of Principal's Supervision Competence and School Culture on Teachers Performance of Public High School in Kutai Kartanegara Regency
}

\author{
Azainil $^{1}$, Ita Kurnia Sabara ${ }^{2}$, Sestuningsih Margi Rahayu ${ }^{3}$, Ramadiani $^{4}$, Widyatmike Gede \\ Mulawarman 5 . \\ \{ azainil@fkip.unmul.ac.id ${ }^{1}$, noni3sabara@yahoo.com², sestuningsih@ fkip.unmul.ac.id ${ }^{3}$, \\ ilkom.ramadiani@gmail.com ${ }^{4}$,widyatmike@fkip.unmul.ac.id $\left.{ }^{5}.\right\}$
}

Faculty of Teacher Training and Education Mulawarman University ${ }^{1,2,5}$, Teacher of SMAN 1 Sebulu Kutai Kartanegara Regency Indonesia ${ }^{3}$, Faculty of Computer Science and Information Technology Mulawarman University.

\begin{abstract}
This study aims to determine the influence of the principal's supervisory competence and school culture on Teachers Performance of Public High School in Kutai Kartanegara Regency. The sample of this study amounted to 118 teachers. Data collection techniques used survey method with data analysis using descriptive statistics and inferential statistics. Data analysis descriptively obtained the average score of principal supervision competence 163,73, the average score of school culture 161,81; and the average teacher performance score of 169.99 in which the three variables fall into the medium category. The result of inferential analysis using multiple linear regression with $5 \%$ significant level shows improvement of one unit of principal supervision competence can cause teacher performance improvement equal to 0,14 unit value at constant 89,39 and one school culture unit can cause teacher performance improvement equal to 0,36 at constant 89.39. The conclusions of this study indicate that there is an influence between the principal's supervision competence and school culture on teacher performance. In other words, the higher the supervisory competence of the school principal and the school culture shows the better the performance of the teacher
\end{abstract}

Keywords: Supervision Competencies, School Culture, Teacher Performance.

\section{Introduction}

The role of the principal is like the heart of the school he leads. The presence of the Principal's supervision is used to advance learning through the growth of the abilities of his teachers. Principal supervision encourages teachers to be more empowered, and teaching and learning situations become better, teaching becomes effective, teachers become more satisfied in carrying out their work, so the education system can function in an effort to improve school quality and achieve educational goals [1]

The reality in the field of the implementation of supervision of the school principal has not gone as expected. According to Purwanto [2] this is influenced by the many factors, including, the community environment around the school is located, the size of the school that is the responsibility of the principal, the level and type of school, the conditions of the teachers and employees available and the principal's skills and expertise own 
The implementation of supervision activities carried out by school principals should be carried out routinely and there will be follow-up after supervision is carried out, but there are still many supervision activities from school principals that have not been running regularly

The teacher is also a determining factor for the success or failure of supervision activities. There are still teachers who do not make learning devices, teachers who carry out the teaching and learning process are not in accordance with the provisions, teachers who do not evaluate learning correctly and feel afraid of the teacher if they will be supervised are the causes of the achievement of supervision objectives to the maximum School culture tells all school people to get along, act, and solve problems in all matters in their school environment [3]. The school's vision and mission are important to be discussed in all schools (principals, teachers, employees, and students), the vision of the school will reflect how the school culture is in the school. In general, many school residents do not know the school's vision and mission because it has never been socialized The habit of developing themselves especially how each member of the school group tries to improve itself and improve the quality of its work is a culture that lives as a tradition that is no longer considered a workload. Likewise with supervision in an effort to improve the quality of learning, if it has been cultured, the teacher who implements it no longer considers that coaching is not a force that comes from outside himself. but rather an upheld academic tradition because it is useful for the school as a whole.

According to Townsend [4], conducive school culture is very important so students feel calm, safe and positive towards their school so that the teacher feels he is valued, and that parents and the community feel accepted and involved. Looking at the actual conditions in schools today shows that not many schools in Indonesia are developing quality improvement plans that focus on developing a school culture

Targets for developing school culture have not been a major concern, and have not become a priority. Another thing that weakens school attention in the development of school culture is the strengthening of school attendance in developing quality in eight national education standards. Formation of schools formally has placed culture as a discourse

Teacher performance can be seen from the four competencies that must be possessed by a teacher, namely pedagogic competence, professional competence, personality competence and social competence [5]. But the fact that there are four competencies is still far from expectations. This can be seen from a number of teacher illnesses that still often arise, such as the origin of class, lack of strategy, lack of discipline, unable to the computer, lack of resources, lack of skill, and ultimately underestimated students. The lack of awareness of how to work well and the motivation to work differently between school principals, teachers and staff resulted in the school's performance is less than optimal. The many diseases of the teacher are part of the phenomenon that arises in the performance of the teacher as an educator which ultimately leads to a weak quality of education.

Based on the description of the background of the problem above, the researcher was interested in carrying out a study on "The Effect of Principal Supervision Competencies and School Culture on Teacher Performance of State High Schools in Kutai Kartanegara District".

The problems in this study include (1) Is there any influence of the principal's supervisory competence on the teacher's performance of public high schools in Kutai Kartanegara District? (2) Is there any influence of school culture on the performance of teachers of Public High Schools in Kutai Kartanegara Regency ?, and (3) Is there any influence between the competence of school principals' supervision and school culture on teacher performance of State High Schools in Kutai Kartanegara Regency? 


\section{Literature Review}

\subsection{Teacher Performance}

Performance is also called work performance. Performance or achievement is defined as an expression of ability based on knowledge, attitudes, skills, and motivation in producing something [6]. Mulyasa [5] argues that performance is a performance of a person who is shown in appearance, action, and work performance as an accumulation of knowledge, skills, values, and attitudes that he has The performance referred to in this study is teacher performance. The growth of the school is very much determined by the performance of the teacher in it. The performance of the teachers as the most important part of the school, the teacher plays a very decisive role in the effort to achieve school goals. The good or bad performance of teachers can be seen in real behavior that is displayed in accordance with the role of the teacher in the school, where this behavior is related to the process of achieving performance results achieved Performance indicators are aspects that become benchmarks in assessing performance. Regulation of the State Minister for State Apparatus Empowerment and Bureaucratic Reform Number 16 of 2009 [7]. confirms that teacher performance assessment is an assessment of each item of the teacher's main task in the context of career development, rank, and position. In this case, it was stated that teacher performance assessments were conducted routinely every year which highlighted 14 (fourteen) competencies for learning teachers, and 17 (seventeen) competencies for Guidance and Counseling teachers, as well as implementing other additional tasks relevant to school functions. The fourteen competencies for the learning teacher in question include teacher competence in 1) recognizing the characteristics of students, 2) mastering learning theory and the principles of educational learning, 3) curriculum development, 4) educational learning activities, 5) potential development students, 6) communication with students, 7) assessment and evaluation, 8) acting in accordance with religious norms, law, social and national culture, 9) showing an adult and exemplary person, 10) work ethic, high responsibility, feeling proud of being a teacher, 11) being inclusive, acting objectively, and not being discriminatory, 12) communication with fellow teachers, education personnel, parents, students and society, 13) mastery of material, structure, concepts and scientific thought patterns that support the eyes lessons learned, and 14) develop professionalism through reflective action.

\subsection{Principal Supervision}

Susanto [6] explains that educational supervision is the main ideas in promoting teacher professional growth, developing democratic leadership, releasing energy, solving problems of teaching and learning creatively. The essence of supervision [2] is as assistance and guidance or professional guidance for teachers in carrying out instructional tasks to improve learning and teaching by carrying out stimulation, coordination, and guidance on an ongoing basis as part of improving the quality of learning The principal as a supervisor must truly understand what assistance is needed by the teacher in implementing and improving his professional quality. Thus supervision by the principal is the process of observing the principal's effectiveness of the work of personnel, especially the teacher, as well as the efficient use of resources used in educational activities in schools so that it leads to improving the quality of education to realize the expected educational goals 


\subsection{School Culture}

According to Deal and Peterson [8], argues that school culture is a set of values that underlie behavior, traditions, daily habits, and symbols that are practiced by principals, teachers, staff, students, and communities around the school. School culture is a characteristic, character or character, and the image of the school in the wider community. Some of the explanations above can be drawn that the school culture is "a pattern of values, norms, attitudes, myths and habits that are formed in the long journey of a school, where the school is held jointly by the principal, teacher, staff, and students, as their basis in understanding and solving various problems that arise in school School culture can be said to be the thoughts, words, attitudes, actions, and hearts of every school citizen that is reflected in their spirit, behavior and symbols and their unique identity slogans. From the above understanding, it can be understood that the concept of school culture is an approach that emphasizes more on the appreciation of the symbolic aspects, traditions, history of the school, all of which will shape the beliefs, selfesteem, and pride of all school people going to school.

\section{Research Methodology}

\subsection{Research Approach and Methodology}

Looking at the problems that will be examined, namely the influence of the principal's supervisory competence and school culture on the teacher's performance of State High Schools in Kutai Kartanegara Regency, the approach used in this study is a quantitative approach. The researcher combines two types of research, namely descriptive research and verification research. Descriptive research aims to obtain a description of variable characteristics, and verification research is a study that aims to determine the relationship between variables through hypothesis testing. The research method used is the survey method.

\subsection{Place and time of research}

This research was conducted at State High Schools located in Zone II Region of Kutai Kartanegara Regency. The place of research will be conducted at 1 Tenggarong Seberang Public High School, Tenggarong Seberang 2 Public High School, Sebulu 1 Public High School, Sebulu 2 Public High School and 1 Muara Kaman Public High School. The research was carried out for 3 months.

\subsection{Data and Data Sources}

In this study, which was determined as the population is the total number of teachers in State High Schools in Zone II Region of Kutai Kartanegara Regency, amounting to 153 people. The sampling technique in this study used Cluster Random Sampling and was taken randomly, meaning researchers took randomly one school from five schools which will be examined to conduct research instrument trials. To determine the size of the study sample, researchers used the entire remaining population after testing research instruments (saturated samples). The sample in this study were teachers of Public High Schools in the Zone II Region of Kutai Kartanegara Regency with a total of 118 people. 


\subsection{Data collection technique}

To obtain the data needed and related to this study, collected through questionnaires in the form of questionnaires designed in the form of instruments that use the previous scale. Therefore the data analysis technique used is

\subsubsection{Descriptive statistics}

This calculation is done to reveal the score distribution of each variable, both the independent variable and the dependent variable. In this study, researchers will present data in the form of a frequency distribution table, accompanied by calculations of mean, median, standard deviation, range, minimum value, maximum value, number and histogram of each variable.

\subsubsection{Inferential Statistics}

To carry out hypothesis testing, namely the requirements that have been fulfilled so that the analysis can be carried out by normality test, linearity test, and homogeneity test. After that, the hypothesis is tested.

\section{Results and Discussion}

\subsection{Results}

\subsubsection{Data Description}

The results of the calculation of Teacher Performance variables (Y) can be seen that as many as 23 respondents $(19.50 \%)$ stated that teacher performance was classified as low, 77 respondents $(65.25 \%)$ stated that they were moderate, and 18 respondents $(15.25 \%)$ said they were high. The calculation results of the Principal Supervision Competency variable (X1) can be seen that as many as 17 respondents $(14.41 \%)$ stated that the supervision of the principal was classified as low, 82 respondents $(69.49 \%)$ stated that they were moderate, and 19 respondents $(16.10 \%)$ said they were high. The results of the calculation of School Culture variables (X2) can be seen that as many as 19 respondents $(16.10 \%)$ stated that the school culture was classified as low, 77 respondents $(65.25 \%)$ stated that they were moderate, and 22 respondents $(18.64 \%)$ said they were high.

\subsubsection{Inferential Statistics \\ 4.1.2.1 Normality test}

This study found that the significance value of the principal's supervision variable was 0.200 , the school culture variable was 0.200 , and the teacher's performance was 0.200 . Because the significance of the data of the three variables is greater than 0.05 , the supervision data of the principal, school culture and teacher performance are stated to be normally distributed.

\subsubsection{Linearity Test}

The results of the linearity test for the supervision of the principal with the teacher's performance are known to be a significance of 0.022 . Because significance is greater than 0.05 , the relationship between school principal supervision and teacher performance is linear. Then the results of the linearity test of the school culture data with the teacher's performance are 
known to have a significance of 0.826 . Because the significance is greater than 0.05 , the relationship between school culture and teacher performance is linear.

\subsubsection{Homogeneity Test}

The homogeneity test is known to be significant, the principal supervising variable 0.601 is more than 0.05 , then the supervision data of the principal is declared homogeneous; significant school culture variable 0.274 , greater than 0.05 , then the school culture data is declared homogeneous; and significantly the teacher performance variable is 0.469 , greater than 0.05 , so the teacher's performance data is declared homogeneous. So it can be concluded that all populations come from homogeneous variances.

\subsubsection{Statistical Hypothesis}

The results of the analysis obtained the regression direction coefficient for the principal supervising variable is 0.164 with a constant of 143.148 . Thus the relationship between the two variables (supervision of the principal and teacher performance) can be described in the equation $\hat{Y}=143.148+0.164 X 1$. This means that an increase in one principal's supervision unit can lead to an increase in teacher performance by 0.164 unit values in the constant 143.148 . Hypothesis testing proves that there is an influence between the supervision of the principal on teacher performance. The results of the analysis obtained the regression direction coefficient for the variability of school culture is 0.372 with a constant of 109.757 . Thus the relationship between the two variables (school culture and teacher performance) can be described in the equation $\hat{Y}$ $=109.757+0.372 \mathrm{X} 2$. This means that an increase in one unit of school culture can lead to an increase in teacher performance by 0.372 units of value at the constant 109.757 . Hypothesis testing proves there is an influence between school culture on teacher performance. The results of the analysis obtained the regression direction coefficient for the principal supervising variable (X1) is 0.136 and the school culture variable (X2) is 0.361 with a constant of 89,393 . Thus the relationship between the three variables (supervision of the principal and school culture with teacher performance) can be described in the equation $\hat{Y}=89,393+0.136 \mathrm{X} 1+0.361 \mathrm{X} 2$. This means that an increase in a principal's supervision unit can lead to an increase in teacher performance by 0.136 units of value at 89,393 constants, and one school culture unit can lead to an increase in teacher performance by 0.361 units of value in 89,393 constants. Hypothesis testing proves that there is an influence between the supervision of the principal and the school culture together on teacher performance.

\subsection{Discussion}

This research proposes three hypotheses. The results of hypothesis testing show that all three submitted are all accepted. In connection with the acceptance of this hypothesis, further discussion needs to be carried out as follows.

\subsection{School Principal Supervision and Teacher Performance}

The first hypothesis in this study was to determine the effect of school principal supervision on teacher performance. The results showed that the supervision of principals had an effect on teacher performance. The results of this study are in line with the research conducted by Suhayati [9], that the performance of teachers will be more professional and quality when balanced with the principal's supervision service that is routine and structured as the tradition and school values that characterize the school. 
Masyhud [10] said that the main purpose of supervision was to help teachers with their own awareness trying to develop and grow to become more capable and better teachers in carrying out their duties. Regarding the duties of the teacher will not be separated from the nature of teacher performance which is the behavior that it produces as an educator. The performance of a teacher will appear in the situations and conditions of daily work in the aspects of activities carrying out their duties

Supervision activities carried out by the principal as a means to provide external motivation in the form of direction, guidance, and assistance to the teacher. The principal can conduct coaching, upgrading, training or in-house training outside the teaching routine which will make the teacher fresher, meaning the teacher gets a new atmosphere and experience, especially those related to the development of self in teacher competence. In addition, teachers are recharged, meaning they are recharged or returned as well as additional enthusiasm for the teacher before they return to carrying out their duties as teachers in learning with students. Everything that has been done by the principal in achieving supervision goals is expected to be able to improve the performance of teachers as educators for the next generation of the nation.

The effect of supervising the principal on teacher performance needs to be accompanied by the consistency and integrity of the principal as a supervisor. Various supervision techniques need to be studied and applied as needed. The same techniques for different needs are not effective in achieving the goals/objectives of the supervision program planned by the principal need to involve other parties such as the vice principal, teachers who already have professional experience and abilities, other school members and the community. The principal as a supervisor has a significant role in mobilizing and improving the performance of all stakeholders, especially teachers

\subsubsection{School Culture and Teacher Performance}

The second hypothesis in this study was to determine the effect of school culture on teacher performance. The results of the study show that school culture influences teacher performance. The results of this study are in accordance with the definition of school culture by Peterson [11] which explains that "School culture is a characteristic of the school that can be identified through the values it embraces, the attitudes it has, the habits it displays and actions shown by all personnel. schools that form a special activity of the school system

The performance of a teacher will appear in the situations and conditions of daily work in the aspects of activities carrying out their duties. The attitude of a teacher and the habits displayed by a teacher is one of the school cultures that influences his performance. A strong school organizational culture will influence every behavior of its citizens. It does not only have an impact on the profits of the school organization in general, but it will also have an impact on the development of the teacher's ability and work effectiveness. School organizational culture can also influence the attitudes and behavior of its members including teacher attitudes that have a consistently positive effect on student achievement

School organizational culture basically represents values, norms, and behaviors that are followed by its members including teachers who are in it. School organizational culture is the most important factor in teacher performance. Teacher performance is an activity carried out by a teacher in learning in accordance with his authority and responsibilities. School organizational culture in which contains values, norms, and attitudes is believed to be able to shape teacher behavior in carrying out activities according to their respective functions and help them understand the value and meaning of work handled in school [11]. Conducive school organizational culture will create quality teacher performance. 


\subsubsection{Principal Supervision, School Culture and Teacher Performance}

The results of the study show that the supervision of the principal and the school culture together influence teacher performance. The results of this study are in line with the research conducted by Suhayati [9], that the performance of teachers will be more professional and quality when balanced with the principal's supervision service that is routine and structured as the tradition and school values that characterize the schoolPrincipal supervision and school culture influence teacher performance. Both of these variables have a fairly high role in improving teacher performance. If the supervision of the principal is carried out routinely and supported by a good school culture it will have a positive impact on teacher performance. Teacher performance will be meaningful if accompanied by strong commitment and sincere intentions and always aware of all the shortcomings that exist in him and strive to continue to be able to increase these deficiencies as an effort to improve in a better direction.

\section{Conclusions}

Based on the results of the analysis and discussion in chapter IV by fulfilling all the requirements for data analysis including normality test, linearity test, and homogeneity test then conducting hypothesis testing, the results of this study can be summarized as follows: (1) Public High School in Kutai Kartanegara Regency. (2). There is an influence of school culture on the performance of teachers of public high schools in Kutai Kartanegara Regency. (3). There is influence between the competence of the principal's supervision and the school's culture on the performance of the teachers of Public High Schools in Kutai Kartanegara District. In accordance with the explanation above, it can be seen from the three hypotheses proposed in this study that all are accepted, so it can be concluded that the teacher's performance of Public High Schools in Kutai Kartanegara Regency can be improved with the supervision competence of principals and school culture. This shows that the higher / routine supervision of the principal, the higher the teacher's performance. Therefore school principals should always make efforts to supervise the principal so that it can improve teacher performance. Likewise, the higher the school culture in a school, the better the teacher's performance

\section{Suggestion}

Based on the results of the research and discussion, some suggestions can be stated as follows: (1) The principal should provide supervision services routinely and structured so that they are able to encourage teachers to become more empowered, and the teaching and learning situation to be better, teaching becomes more satisfied in carrying out his work. (2) Principals should always provide an understanding of all school components in order to always maintain tradition, school values that characterize the school and strengthen a positive school culture but more importantly is a culture for continuous improvement in school quality. (3) For teachers, teacher teaching performance will be more professional and quality by applying improved approaches to students or improving self-training as educators so that teachers are more motivated to work so that learning effectiveness will be better, and (4) For Schools, Creating schools as a harmonious, healthy, dynamic and comfortable work environment so that all members can work with full productivity and gain high job satisfaction. 


\section{References}

[1] Azainil, A., Apriliani, N. U., \& Suandie, S. (2018). Policy Evaluation Total Quality Management (TQM) School Applying International Organization for Standardization (ISO) in the City of Samarinda. Journal Of Educational Review and Research, 1(1), 25-37

[2] Purwanto, M. N. (2010). Administrasi dan supervisi pendidikan. Remadja Karya..

[3] Engels, N., Hotton, G., Devos, G., Bouckenooghe, D., \& Aelterman, A. (2008). Principals in schools with a positive school culture. Educational Studies, 34(3), 159-174

[4] Townsend, T., \& MacBeath, J. (Eds.). (2011). International handbook of leadership for learning (Vol. 25). Springer Science \& Business Media

[5] Mulyasa, (2013).. Uji Kompetensi dan Penilaian Kinerja Guru. Bandung : Remaja Rosdakarya.

[6] Susanto, A. (2016). Manajemen Peningkatan Kinerja Guru. Jakarta : Prenada Media Group.

[7] Peraturan Menteri Negara Pemberdayaan Aparatur Negara dan Reformasi Birokrasi Nomor 16 Tahun 2009

[8] Deal, T. E., \& Peterson, K. D. (1999). Shaping school culture: The heart of leadership. Adolescence, 34(136), 802.

[9] Suhayati, I. Y. (2017). Supervisi Akademik Kepala Sekolah, Budaya Sekolah Dan Kinerja Mengajar Guru. Jurnal Administrasi Pendidikan, 17(1).

[10] Masyhud, S. (2014). Manajemen Profesi Kependidikan. Yogyakarta: Kurnia Kalam Semesta..

[11] Peterson, K. D., \& Deal, T. E. (2011). The shaping school culture fieldbook. John Wiley \& Sons.

[12] Dipaola, M., \& Hoy, W. K. (2013). Principals improving instruction: Supervision, evaluation, and professional development. IAP.

[13] Waldron, N. L., \& McLeskey, J. (2010). Establishing a collaborative school culture through comprehensive school reform. Journal of Educational and Psychological Consultation, 20(1), 58-74 